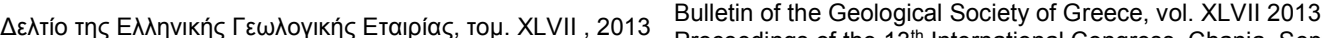
Proceedings of the $13^{\text {th }}$ International Congress, Chania, Sept.

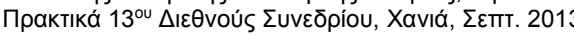
2013

\title{
DRASTIC METHOD TO MAP GROUNDWATER VULNERABILITY TO POLLUTION USING NITRATE MEASUREMENTS IN AGRICULTURAL AREAS
}

\author{
Samara T. ${ }^{1}$ and Yoxas G. ${ }^{2}$ \\ ${ }^{I}$ National and Kapodistrian University of Athens, Faculty of Geology and Geoenvironment, \\ Department of Dynamic Tectonic \& Applied Geology,tsamara@geol.uoa.gr \\ 2AquaScience Consulting, Geological and Environmental Office Services,yoxas@aquascience.gr
}

\begin{abstract}
DRASTIC model has been used to map groundwater vulnerability to pollution in many areas. Since this method is used in different places without any changes, it cannot consider the effects of pollution type and characteristics. Therefore, the method needs to be calibrated and corrected for that aquifer and specific land use. In this research, by correcting the rates of DRASTIC parameters, one can assess the vulnerability potential to pollution more accurately. The new rates were computed using the relationships between DRASTIC INDEX (DI) corresponding to land use and to nitrate concentration in groundwater. The proposed methodology was applied in deltaic region of alluvial aquifer of Volinaios catchment located in the northwestern part of Peloponnesus. In order to determine the quality of the ground waters, either for watering or irrigating purposes, in the study area, a sampling was made. Correlation was used to find the relationship between the index and measured pollution in each point and therefore, to modify the rates. The results showed that the modified DRASTIC is better than the original method for nonpoint source pollution in agricultural areas.
\end{abstract}

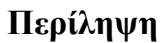

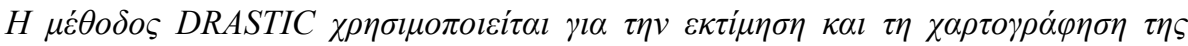

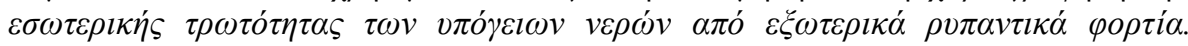

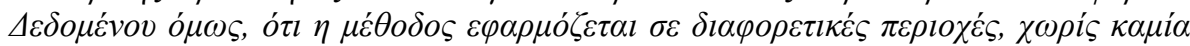

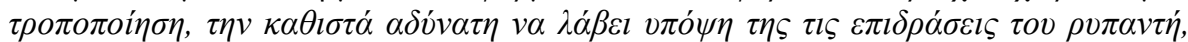

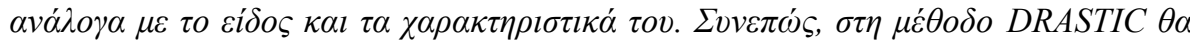

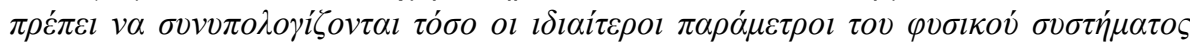

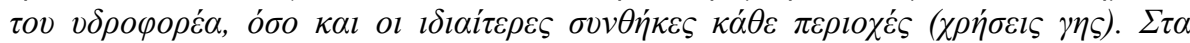

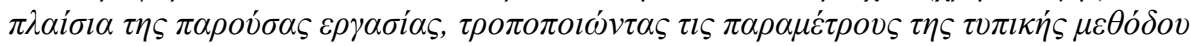

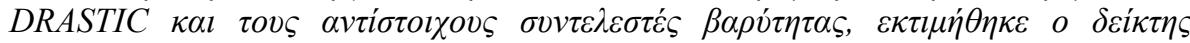

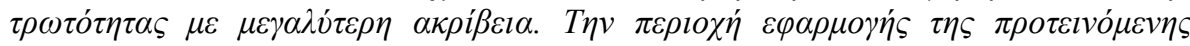

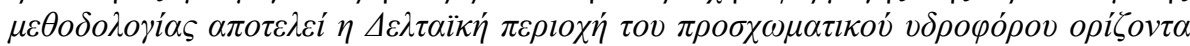

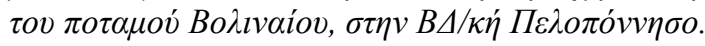




\section{Introduction}

The concept of vulnerability is associated with the capacity with which a contaminant that has penetrated the soil surface reaches the aquifer, under specific land use management practices in an area of interest, while the characteristics of the contaminant and the aquifer sensitivity are set.

Vulnerability maps provide a more or less subjective view of the ability of the subsoil, to protect groundwater especially in terms of quality. The basic purpose of these maps is to divide an area into more classes, each of which will represent a different dynamic for a specific purpose and use. (Vrba\&Zaporozec, 1994). The main methods of mapping and assessing intrinsic vulnerability in porous media are the following: DRASTIC (Aller et al., 1987), AVI (Van Stempvoort et al., 1993), GOD (Foster, 1987) and others. In this paper the DRASTIC method was applied, which is an index method based on hydrogeological parameters. A modification to the original method was attempted in order to include anthropogenic activity, which is extensive in the area, by adding an extra parameter that of land use. In order to assess the results, a correlation between these and nitrate ion concentration was made.

\section{Methodology}

The main purpose of this paper is to describe, analyze, and interpret, the geological, hydrogeological and hydrochemical conditions of the study area, in order to identify sites according to contaminant sensitivity. For this stage, the original DRASTIC method was used.

The title of this method comes from the abbreviation of the parameters taken into account: D (Depth to water), R (Recharge rate), A (Aquifer media), S (Soil cover), T (Topography), I (Impact of vadose zone) and C (Conductivity of the aquifer). The DRASTIC index (DI) is calculated by the following equation:

$$
\mathrm{DI}=\sum_{\mathrm{i}=1}^{7} r_{i} \cdot w_{i}
$$

where $\mathrm{r}$, is the value of the parameter, and $\mathrm{w}$ is the value of the weighted factor. It should be noted that the grater the DI value, the greater the contaminant sensitivity of the area.

Table 1 presents the weighted factor of each parameter. It is obvious that depth to water and impact of vadose zone, are the parameters with the greater weighted factor values.

Table 1 -Assigned Weights for Typical DRASTIC parameters.

\begin{tabular}{|c|c|}
\hline Parameter & Weight \\
\hline Depth to water & 5 \\
\hline Recharge & 4 \\
\hline Aquifer media & 3 \\
\hline Soil cover & 2 \\
\hline Topography & 1 \\
\hline Impact of vadose zone & 5 \\
\hline Conductivity of the aquifer & 3 \\
\hline
\end{tabular}

Considering the fact that the causes of groundwater contamination are mainly anthropogenic, in addition to the fact that in the original DRASTIC method anthropogenic activity is not taken into account, the modified DRASTIC method was proposed. This method uses an additional parameter that of land uses, to include anthropogenic impact on an area.

XLVII, No $2-982$ 


\section{Description of the Study Area}

The study area includes the deltaic region of the alluvial aquifer of the river Volinaios. It is located in the northwestern area of Peloponnese, in the Achaea regional unit, approximately $15 \mathrm{~km}$ east of the city of Patra and consists of an approximately $11 \mathrm{~km}^{2}$ area. The average annual temperature reaches up to $19,1^{\circ} \mathrm{C}$ and the average annual rainfall height, up to $972 \mathrm{~mm}$. According to the approximate hydraulic balance equation estimated in the study area, the actual evapotranspiration is $60.8 \%$ of the average annual rainfall height $(591 \mathrm{~mm})$, the recharge area is $19.2 \%$, and infiltration is $20 \%$ (Yoxas, 2004).

In terms of geology, the study area consists of post-Alpine sediments, which are divided into two main units:

- Pliocene-Pleistocene sediments, that consist of a conglomerate formation, a marl formation and a sand clay formation and

- Holocene sediments, that consists of alluvial deposits and scree cones.

These units are related to the folded Alpine bedrock via an angled unconformity that consists of Cretaceous pelagic and platy limestones of the Pindos Unit (Koukouvelas and Papadopoulos, 1984).

In the study area occur permeable and semi-permeable formations, which behavior depends on grain size, thickness and stratigraphic position. Therefore, alluvial and debris cone formations are characterized as permeable, while marl and sandy clay and conglomerate formations are characterized as semi-permeable. Within the alluvial formation is developed the main aquifer of the study area.

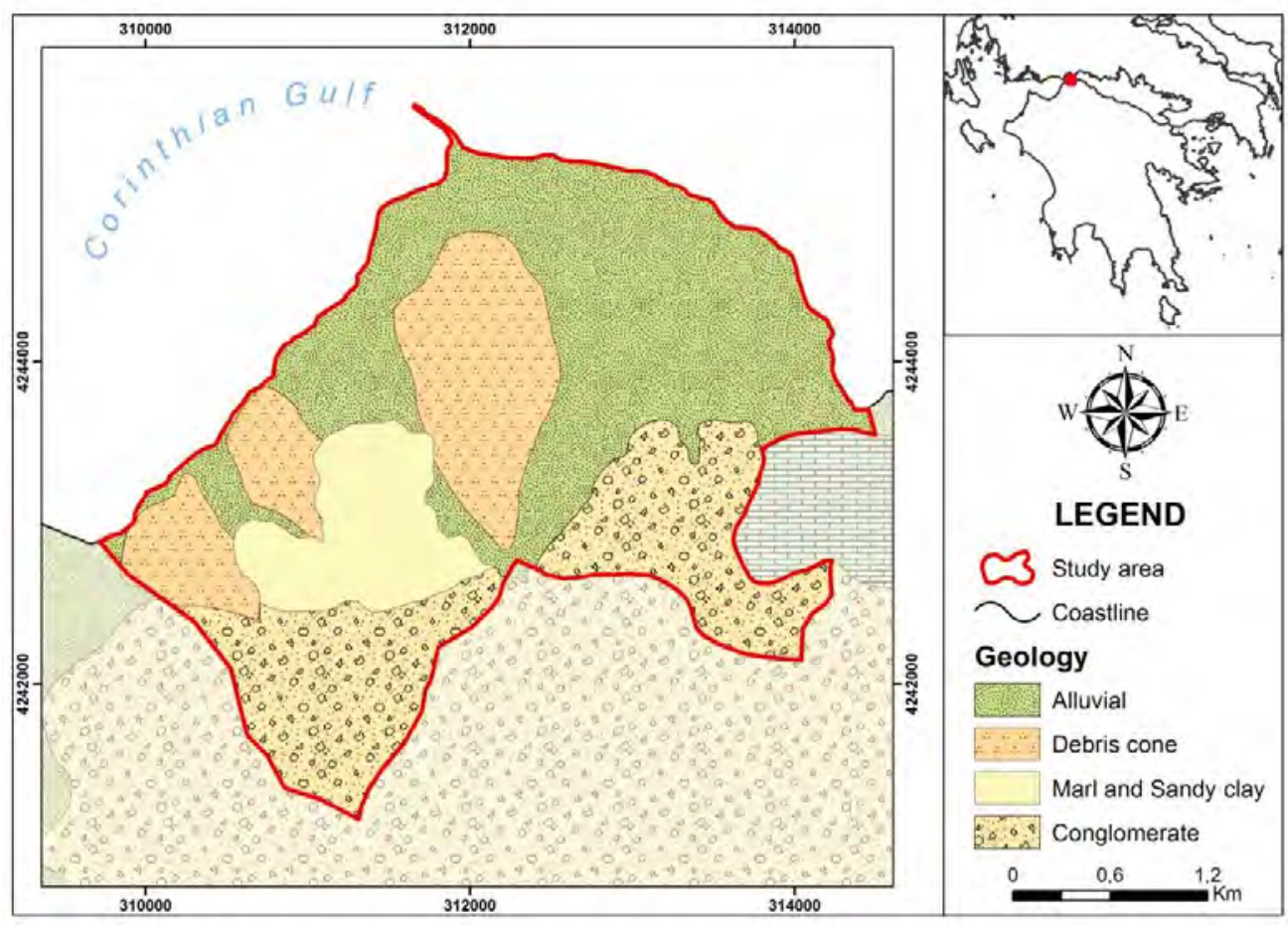

Figure 1 - Geological map of the study area (Tsoflias, 1971, modified).

According to the piezometric map (Figure 2), the hydraulic gradient ranges from $5 \%$ to $8 \%$, the general flow direction is NW and the hydraulic head ranges between $+14 \mathrm{~m}$ to $0 \mathrm{~m}$ in coastal areas (Yoxas, 2004). 


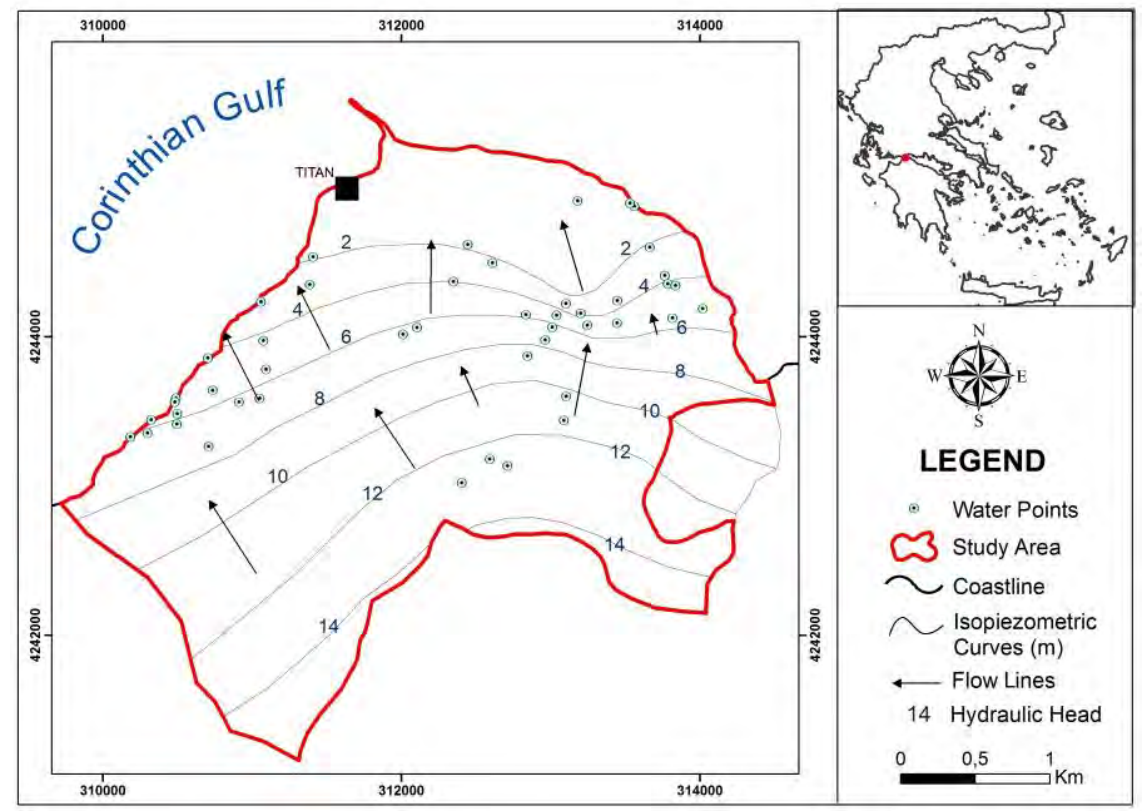

Figure 2 - Piezometric map of the study area.

\section{Hydrochemical Conditions}

Observation and assessment of the physical-chemical parameters of the water in the study area is imperative in order to project an image of the current quality conditions, and to verify the results of the vulnerability assessment methods (Table 2).

Table 2 - Summary statistics of physicochemical parameters of the alluvial aquifer.

\begin{tabular}{|c|c|c|c|c|c|c|c|}
\hline \multirow{2}{*}{ Parameter } & \multirow{2}{*}{ Units } & \multicolumn{3}{|c|}{ Dry Period } & \multicolumn{3}{c|}{ Wet Period } \\
\cline { 3 - 8 } & & Min & Max & Avg & Min & Max & Avg \\
\hline $\mathrm{pH}$ & - & 6.89 & 8.1 & 7.372 & 6.72 & 7.95 & 7.318 \\
\hline $\mathrm{Eh}$ & $(\mathrm{mV})$ & 22 & 269 & 179.1 & -175 & 270 & 139.897 \\
\hline $\mathrm{T}$ & $(\mathrm{oC})$ & 10.7 & 19.2 & 15.92 & 10.9 & 23.5 & 16.682 \\
\hline $\mathrm{E} . \mathrm{C}$. & $(\mu \mathrm{S} / \mathrm{cm})$ & 153 & 2040 & 635.1 & 139 & 1690 & 596.231 \\
\hline $\mathrm{Na}^{+}$ & $\mathrm{mg} / \mathrm{L}$ & 2.682 & 143.322 & 24.777 & 5.659 & 137.072 & 33646 \\
\hline $\mathrm{K}^{+}$ & $\mathrm{mg} / \mathrm{L}$ & 0.598 & 3.984 & 1.702 & 1.469 & 7.752 & 2.652 \\
\hline $\mathrm{Mg}^{2+}$ & $\mathrm{mg} / \mathrm{L}$ & 0 & 27.134 & 4.162 & 0.001 & 26.512 & 9.079 \\
\hline $\mathrm{Ca}^{2+}$ & $\mathrm{mg} / \mathrm{L}$ & 42.456 & 196.394 & 118.968 & 11.704 & 213.428 & 91.275 \\
\hline $\mathrm{NH}_{4}{ }^{+}$ & $\mathrm{mg} / \mathrm{L}$ & 0 & 12.642 & 0.655 & 0 & 2.792 & 0.24 \\
\hline $\mathrm{Cl}^{-}$ & $\mathrm{mg} / \mathrm{L}$ & 2.7 & 361 & 51.09 & 3.98 & 344 & 33.018 \\
\hline $\mathrm{Br}^{-}$ & $\mathrm{mg} / \mathrm{L}$ & 0 & 3.866 & 0.533 & 0.07 & 2.95 & 0.358 \\
\hline $\mathrm{SO}_{4}{ }^{2-}$ & $\mathrm{mg} / \mathrm{L}$ & 0 & 102 & 44.8 & 0 & 155.2 & 37.931 \\
\hline $\mathrm{NO}_{3}{ }^{-}$ & $\mathrm{mg} / \mathrm{L}$ & 9.68 & 38.72 & 19.226 & 1.32 & 79.2 & 13.009 \\
\hline $\mathrm{HCO}_{3}{ }^{-}$ & $\mathrm{mg} / \mathrm{L}$ & 112.24 & 434.32 & 258.884 & 107.36 & 484.34 & 266.179 \\
\hline $\mathrm{O}_{2}$ & $\mathrm{mg} / \mathrm{L}$ & 2.8 & 10.1 & 7.46 & 0.9 & 14.4 & 0.072 \\
\hline
\end{tabular}

$\underline{\text { XLVII, No } 2-984}$ 
The chemical analysis (Yoxas, 2004) included defining each of the following physical parameters: Temperature ( $\mathrm{T}_{\mathrm{wa}}$ ), electrical conductivity (E.C.), $\mathrm{pH}$, redox potential (Eh), dissolved oxygen $\left(\mathrm{DO}_{2}\right)$, and the following chemical parameters: $\mathrm{Na}^{+}, \mathrm{K}^{+}, \mathrm{Mg}^{2+}, \mathrm{Ca}^{2+}, \mathrm{NH}_{4}^{+}, \mathrm{Cl}^{-}, \mathrm{Br}^{-}, \mathrm{SO}_{4}^{2-}, \mathrm{NO}_{3}{ }^{-}$, $\mathrm{NO}_{2}^{-}, \mathrm{HCO}_{3}^{-}, \mathrm{O}_{2}$

In order to verify the results of the application of both methods, data from hydrochemical analysis and in particular those of nitrate ions were used, because of their anthropogenic origins.

By observing the spatial distribution map of nitrate ions (Figure 3), an increase in the concentration of nitrate ions is noted in both the western and eastern section of the study area. In the northern, central and southwestern section, the lowest values are observed.

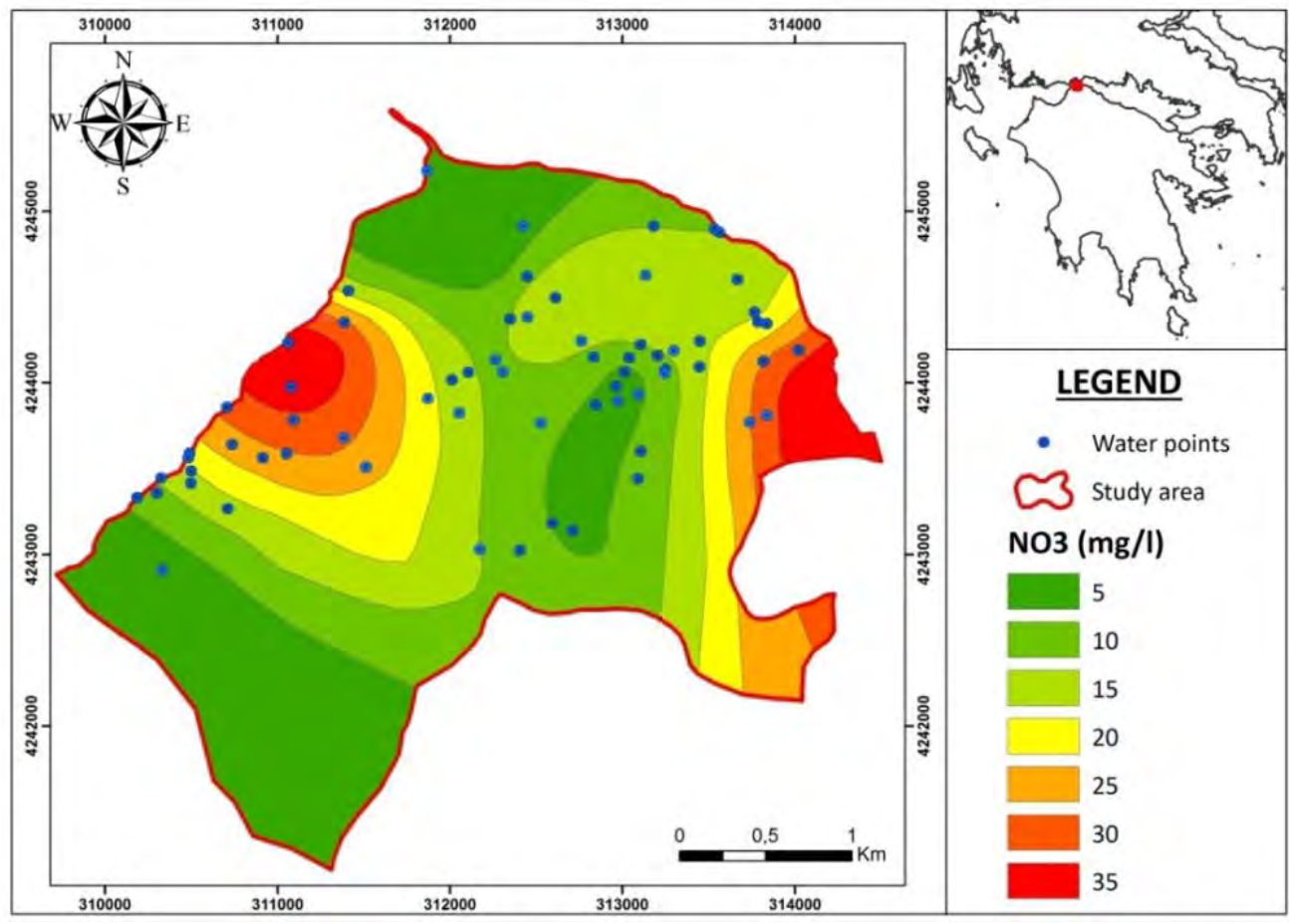

Figure 3 - Map of spatial distribution of nitrate $\left(\mathrm{NO}_{3}{ }^{-}\right)$.

\section{Methods of Assessment and Vulnerability Mapping}

\subsection{Typical DRASTIC Method}

In order to apply this method, geological, geomorphological, hydrological, hydrogeological and soil data were used, that originated from fieldwork collected data, combined with information collected from correlation data from 64 boreholes in the study area. In addition, using topography maps from the Hellenic Military Geographical Survey on 1:5.000 and 1:50.000 scales, the Digital Elevation Model (DEM) was created to calculate morphological slope. For each parameter, a thematic layer was created along with the relative calibration values. The final vulnerability index map resulted from the combination of the various thematic layers according to the original DRASTIC method.

\subsubsection{Depth to Water (D)}

The value of parameter D was obtained using piezometric maps. This parameter defines the vertical distance needed for a contaminant to reach the aquifer. The greater the distance, the better the groundwater is protected from contamination and the lower its value (Table 3 ). 


\subsubsection{Recharge (R)}

This parameter represents the annual water quantity in $\mathrm{mm}$ that infiltrates into the soil surface and reaches the aquifer. The greater the quantity of water infiltrated, the greater the recharge, and consequently, the greater the possibility of contamination (Table 3 ).

\subsubsection{Aquifer Media (A)}

Aquifer material plays an important part to the length of the distance and to the pathway through which a contaminant is transported. In general, the greater the size of the grains of the aquifer material, the greater the porosity is and therefore the lower the deterioration capacity of the contaminant. Consequently, the greater the grain size, the higher the value in the evaluation system (Table 3). Data of the aquifer media are from the lithological intersection of 64 boreholes in the study area (Yoxas, 2004).

Table 3 - Ranges and Ratings for each parameter.

\begin{tabular}{|c|c|c|}
\hline Parameter & Range & Rating \\
\hline \multirow{4}{*}{ Depth to water(m) } & $0-4$ & 9 \\
\hline & $4-8$ & 8 \\
\hline & $8-12$ & 7 \\
\hline & $>12$ & 6 \\
\hline \multirow{3}{*}{ Recharge(mm/year) } & $200-300$ & 6 \\
\hline & $100-200$ & 4 \\
\hline & $<100$ & 2 \\
\hline \multirow{4}{*}{ Aquifer media } & Pebble & 7 \\
\hline & Pebble - Gravel & 6 \\
\hline & Gravel - Sand & 4 \\
\hline & Gravel-Sand-Clay & 2 \\
\hline \multirow{3}{*}{ Soil cover } & Rock & 8 \\
\hline & Deep - Shallow & 5 \\
\hline & Deep & 2 \\
\hline \multirow{5}{*}{ Topography (\%) } & $0-2$ & 10 \\
\hline & $2-6$ & 9 \\
\hline & $6-12$ & 5 \\
\hline & $12-18$ & 3 \\
\hline & $>18$ & 1 \\
\hline \multirow{4}{*}{ Impact of vadose zone } & Pebble - Gravel & 9 \\
\hline & Gravel - Sand & 7 \\
\hline & Sand & 5 \\
\hline & Clay-Sand & 3 \\
\hline \multirow{3}{*}{ Conductivity (m/day) } & $4-10$ & 6 \\
\hline & $2-4$ & 4 \\
\hline & $<2$ & 2 \\
\hline
\end{tabular}




\subsubsection{Soil Cover (S)}

The thicker the soil cover, the greater possibility that the contaminant will endure deterioration mechanisms, due to the existing water deposition, that constitutes an important protective mechanism, before it reaches deeper water bodies. Consequently, the thicker the existing soil covers above the formation, the lower the value of the evaluation system (Table 3 ).

\subsubsection{Topography $(T)$}

Low slope values favor infiltration and are associated with greater vulnerability, in opposition to greater slope values, which favor recharge and are associated with low vulnerability. Slopes were set by using the Digital Elevation Model. The lower slope values were graded with a high value in the evaluation system, whereas greater values were graded with a lower value (Table 3 ).

\subsubsection{Impact of Vadose Zone (I)}

Vadose zone is the subsoil zone above the aquifer level. It plays an important role lessening the contaminant charge, due to the different existing mechanisms that cause its deterioration. (geochemical, physical, biochemical etc.).

In consequence, the vadose zone material is of crucial importance for the evaluation of this parameter. The greater the grain sizes of the vadose zone material, the greater the value in the evaluation system (Table 3 ).

\subsubsection{Conductivity of the Aquifer (C)}

Hydraulic conductivity represents the velocity with which a contaminant is transported through the saturation zone. Its value is dependent on the attributes and characteristics of the aquifer. The greater the hydraulic conductivity is, the faster the place with which contaminants are transported and the greater their vulnerability to contamination. Hydraulic conductivity was allocated by evaluating drills that took place in the study area. Therefore the greater the hydraulic conductivity, the greater the value in the evaluation system (Table 3).

\subsubsection{Drastic Index (DI)}

According to the criteria taken into account in the original DRASIC method and according to the relative weighted indexes, the creation of the final vulnerability map was feasible. (Figure 4) DI values are divided into four (4) classes and are presented in Table 4.

Table 4- Values of the respective classes.

\begin{tabular}{|c|c|}
\hline Drastic Index & Classes \\
\hline$<79$ & Very low \\
\hline $80-99$ & Low \\
\hline $100-119$ & Medium \\
\hline$>120$ & High \\
\hline
\end{tabular}

As it is concluded by the final vulnerability index map, the higher values (DI $>100)$ are observed in the eastern and western section, covering $19.86 \%$ of the study area. The sections with the lower vulnerability index $(80<\mathrm{DI}<99)$ cover the greatest area, a percentage of $45.34 \%$. Finally, areas with the lowest values of the index are located in the central-northwestern section of the study area, while some of them are sparsely observed throughout the southeastern and southwestern area. This covers an area of $33.53 \%$. 


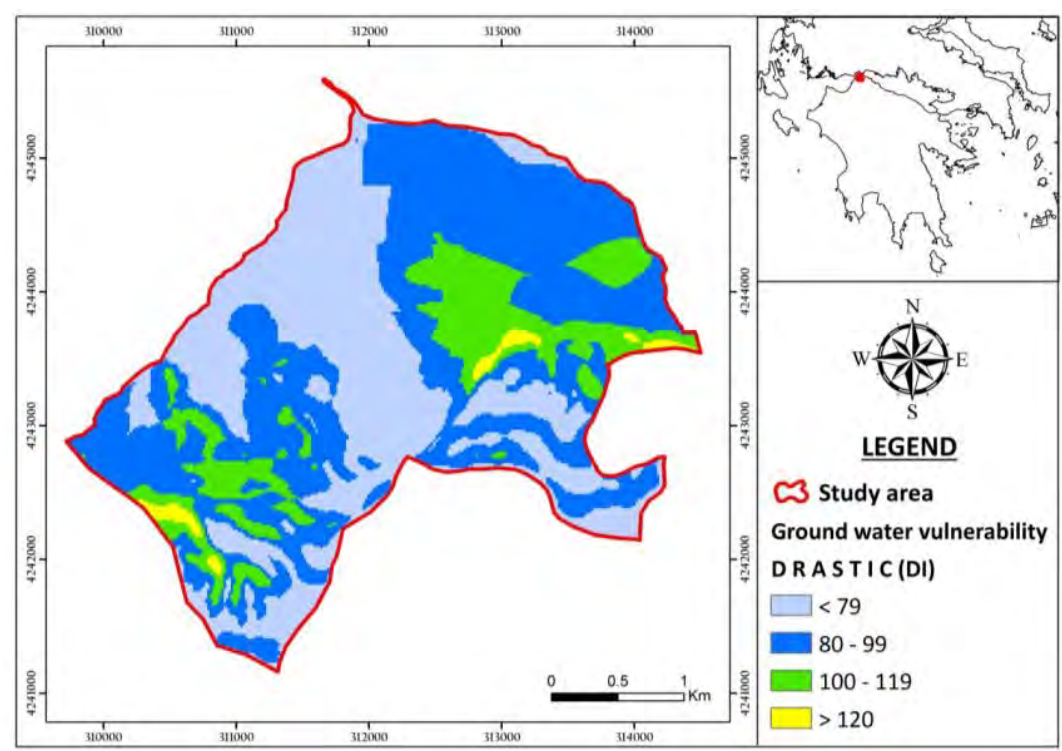

Figure 4 - Distribution map of the Drastic Index (DI).

\subsection{Modified DRASTIC-L Method}

Taking into consideration the land uses of the study area developed by Corine Land Cover 2004 (US Protection Agency, 1985) and the methodology being applied by Secunda et al. (1998), Al-Adamat et al. (2002), the modified DRASTIC index equation is:

$$
\mathrm{MDI}=\sum_{\mathrm{i}=1}^{8} r_{i} \cdot w_{i}
$$

where MDI = Modified Drastic Index

In order to introduce a land use factor into the DRASTIC index, the land use map (Figure 5) was rated according to the weighted values.

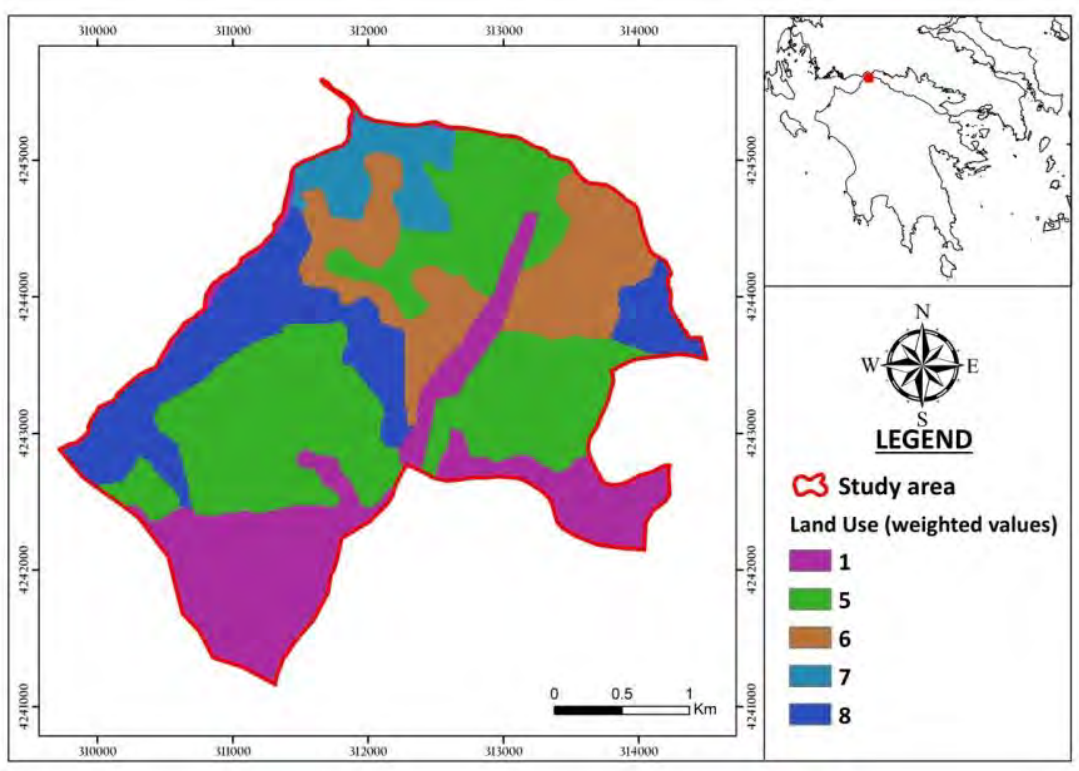

Figure 5 - Land Use criterion with weighted values.

$\underline{\text { XLVII, No } 2-988}$ 
This map was converted into a raster grid and the resultant grid coverage was then added to the DRASTIC index based on equation. 2 (modified from Secunda et al. 1998).

Table 5 - Ranges and Ratings for each parameter.

\begin{tabular}{|c|c|c|c|c|c|c|c|c|c|c|}
\hline Parameter & Criteria & D & R & A & S & T & I & C & L & Priority \\
\hline Depth to water (m) & D & 1 & 4 & 5 & 2 & 2 & 1 & 5 & 2 & $\mathbf{0 . 2 4 6 2}$ \\
\hline Recharge (mm/year) & R & $1 / 4$ & 1 & 4 & $1 / 2$ & $1 / 2$ & $1 / 2$ & 1 & $1 / 2$ & $\mathbf{0 . 0 7 5 7}$ \\
\hline Aquifer media & A & $1 / 5$ & $1 / 4$ & 1 & $1 / 4$ & $1 / 4$ & $1 / 3$ & 1 & $1 / 4$ & $\mathbf{0 . 0 3 7 5}$ \\
\hline Soil cover & S & $1 / 2$ & 2 & 4 & 1 & $1 / 2$ & 2 & 3 & 1 & $\mathbf{0 . 1 4 1 9}$ \\
\hline Topography (\%) & T & $1 / 2$ & 2 & 4 & 2 & 1 & 3 & 3 & 1 & $\mathbf{0 . 1 8 3 2}$ \\
\hline Impact of vadose zone & I & 1 & 2 & 3 & $1 / 2$ & $1 / 3$ & 1 & 2 & $1 / 2$ & $\mathbf{0 . 1 1 1 4}$ \\
\hline Conductivity (m/day) & C & $1 / 5$ & 1 & 1 & $1 / 3$ & $1 / 3$ & $1 / 2$ & 1 & $1 / 3$ & $\mathbf{0 . 0 5 1 2}$ \\
\hline Land Use & L & $1 / 2$ & 2 & 4 & 1 & 1 & 2 & 3 & 1 & $\mathbf{0 . 1 5 2 9}$ \\
\hline
\end{tabular}

Consistency Ratio $(C R)=0.0372<0.1$

The preparation of the final map was the result of the combination among the thematic maps with respect to Analytical Hierarchy Process (Saaty 1977, 2003). The AHP parameters as well as its analysis are shown in table 5, indicating the priority vectors of all criteria.

From the combination of the above thematic maps, using the tool Spatial Analyst of ArcGIS, revealed the final map identifying areas of vulnerability, on a scale grading from low to high values respectively (Figure 6).

Using the classification methodology derived from the AHP analysis, the modified DRASTIC-L index was sub - derided into 4 classes, (i) below 79 with very low risk, (ii) 80 - 99 with low risk and (iii) 100 - 119 with medium risk and (iv) above 120 with high risk.

According to AHP analysis, criterion 8 (Land Use), takes high weighted value as well as criterion 1 and criterion 5 respectively. The land use criterion provides a basis for specific assessment in future work.

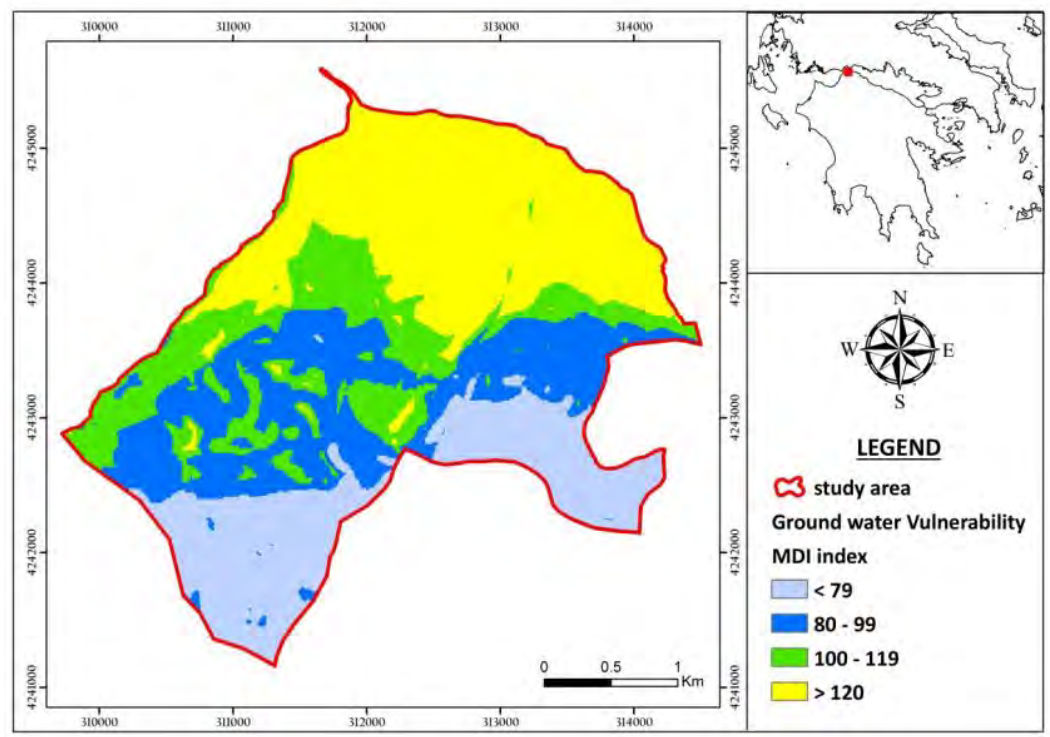

Figure 6 - Distribution map of the Modified Drastic Index (MDI).

$\underline{\text { XLVII, No } 2-989}$ 
The role of land use due to its importance of evaluating the potential effect upon ground water quality resulting from the fact that areas having high values of ground water vulnerability appears to be explained by intense irrigating agricultural zones. As shown in Figure 6, ground water vulnerability increases as the suitability index increases.

\section{Groundwater Vulnerability and Nitrate Concentrations in Groundwater}

In order to estimate the affection of land use; a correlation between nitrate ions and MDI factor was made. Nitrate contamination has been suggested as an indicator of overall groundwater quality $^{1}$ (2006/118/EC). Because drinking water with high nitrate concentrations is a potential health risk, European Union (2006) has set a minimum standard for nitrate in drinking water of 50 $\mathrm{mg} / \mathrm{L}$. Identifying areas in the study area where ground water has been impacted by anthropogenic activities (nitrate concentrations at or above $3 \mathrm{mg} / \mathrm{L}$ ) can help water resource managers protect the water supply by targeting land-use planning and monitoring programs to these vulnerable areas.

According to the distribution map of nitrate composition in groundwater (Figure 3), samples with high values of nitrate composition are seem to be into area with high values of MDI factor. Additionally, low vulnerability zones (low MDI factor) are located into samples with low values of nitrate composition respectively.

By the comparison of concentration of nitrate ions with the results of MDI factor, an interconnection was observed and the correlation factor of cross-plot of these parameters is ordered $70 \%$ (Figure 7). Finally, regions with high vulnerability zones were established mainly due to human activities which are intensive in those areas.

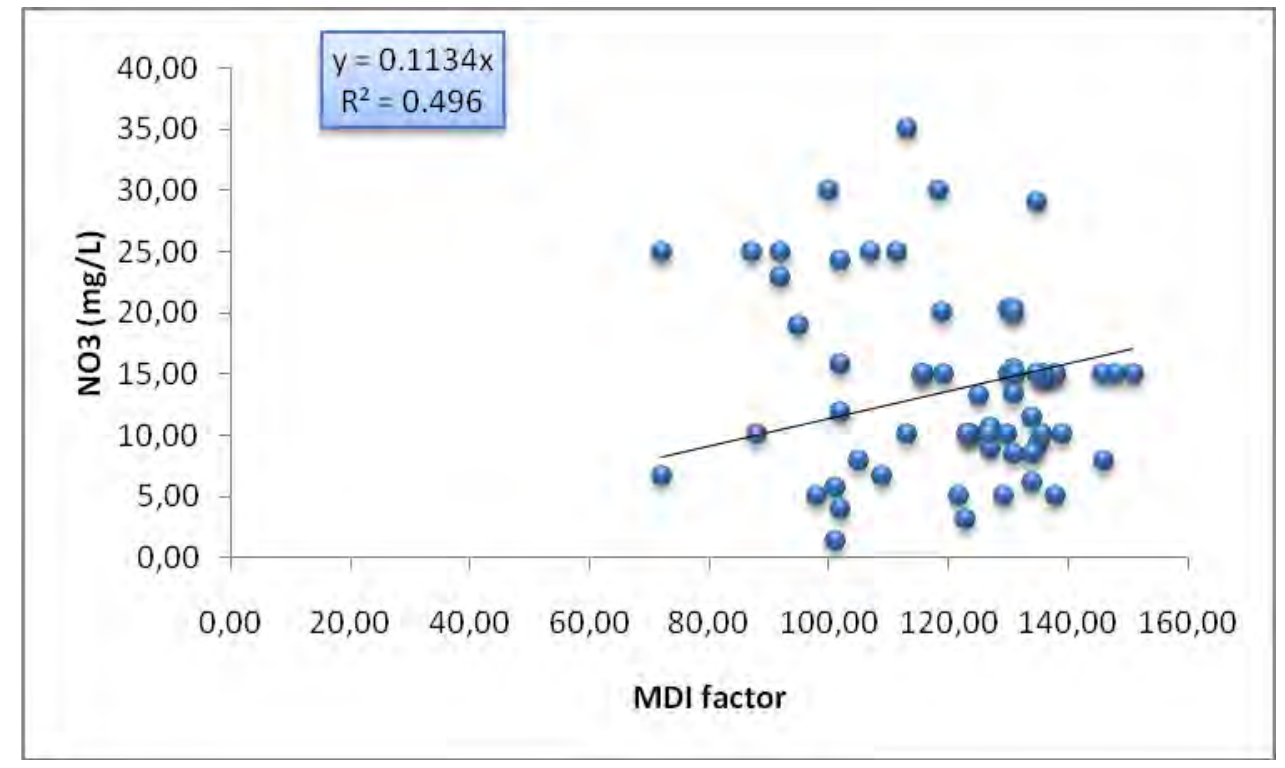

Figure 7 - Cross - plot diagram of nitrate concentration vs MDI factor

\section{Conclusion - Discussion}

The study area is characterized by several sources of pollutions due to anthropogenic activities. In intensive agricultural areas, continuous recharge of treated effluents and other water used for irrigation can change the configuration of the soil and the subsoil media, leading to higher

\footnotetext{
${ }^{1}$ European Union (2006) Water Framework Directive 2006/118/EC of the European Parliament and of the Council, Official Journal of the European Union
}

$\underline{\text { XLVII, No } 2-990}$ 
hydraulic conductivity and therefore higher percolation to groundwater of much kind of pollutants. MDI method indicates these areas where long-term land use activities increase natural potential vulnerability to groundwater pollution, as assessed by original DRASTIC.

Comparing the final MDI value map with the nitrate composition in ground water, it is obvious that areas with high values of MDI factor overlaid to areas with intense anthropogenic activities.

The run of MDI model was derived from AHP analysis which laid to the conclusion that land use factor plays a strong role as it takes high weighted value as well as criterion 1 and criterion 5 respectively.

The final DRASTIC model was tested using hydrochemical data from the aquifer. The analysis of groundwater chemistry was encouraging to find that no sample point with high nitrate levels was found in the areas classified as being of low risk suggesting that the original DRASTIC model for this area provided a conservative estimate of low risk areas.

It is recognized that the approach adopted to produce the DRASTIC index in areas with either intense agricultural activity and coastal aquifer provides important objective information that could be used to inform local decision making.

\section{References}

Al-Adamat R.N.A. 2002. The use of Geographical Information Systems (GIS) and Remote sensing to investigate Groundwater Quality in the Azraq Basin, Jordan, Unpublished PhD Thesis, Coventry University, Coventry UK.

Aller L., Bennett T., Lehr J.H. and Petty R.J. 1987. DRASTIC: A Standardized System for Evaluating Ground water Potential Using Hydrogeological Settings, Environmental Research Laboratory, US Environmental Protection Agency. Ada Oklahoma, EPA/600/2$85 / 018$.

European Union (2006) Water Framework Directive 2006/118/EC of the European Parliament and of the Council, Official Journal of the European Union

Foster S.S.D. 1987. Fundamental concepts in aquifer vulnerability, pollution risk and protection strategy. In: Van Duijvenbooden W., Weageningh H.G. (eds) TNO Committee on Hydrological Research, The Hague, Vulnerability of soil and groundwater to pollutants, Proc. Inf. 38, $69-86$.

Koukouvelas I. and Papadopoulos Ch. 1984. Geological study of Argyra - Sela - Ag. Vasileios Dissertation, University of Patras, pp: 27 (in Greek).

Saaty T.L. 2003. Decision making with the AHP: Why is principal eigenvector necessary, European Journal of Operational Research, vol. 145, pp: 85 - 91.

Saaty T.L. 1977. A scaling method for priorities in hierarchical structures, Journal of Mathematical Psychology 15, $231-281$

Secunda S., Collin M.L. and Melloul A. J. 1998. Groundwater vulnerability assessment using a composite model combining DRASTIC with extensive agricultural land use in Israel's Sharon region, Journal of Environmental Management, vol. 54, pp: 39-57

Tsoflias P. 1971. Geological map of Greece, scale 1:50000, Nafpactos sheet, IGME, Athens.

Vrba J. and Zaporozec A. 1994. Guidebook on Mapping Groundwater Vulnerability, International Contributions to Hydrogeology (IAH), vol. 16, pp: 131.

US Protection Agency 1985. DRASTIC: a Standard System for Evaluating Groundwater Potential Using Hydrogeological Settings, Ada, Okla., NWWA/EPA Series.163 pp.

Van Stempvoort D., Ewart L. and Wassenaar L. 1993. Aquifer vulnerability index: a GIScompatible method for groundwater vulnerability mapping, Canadian Water Resources Journal vol. 18, pp:25-32

Yoxas G. 2004. Hydrogeological and hydrochemical conditions of alluvial aquifer of Volinaios catchment, NW Peloponnesus, Dissertation, University of Patras. 